\title{
脳神経外科領域における最近の進歩と動向
}

\author{
中沢 省三* \\ 日本医科大学譄神経外科学教室
}

\begin{abstract}
はじめに
脳神経外科項域に顕微鏡手術（microsurgery）が導 入されたのか゚ 1960 年代であり, それから約 10 年後 の 1970 年代にX線コンピュータ断層撮影 (Computed tomography, CT) が導入された. この診断と治療面 における二つの新しい技術の導入により, 近代腷神経 外科は実に革命的ともいえるほどの進步発展を遂げる に至った. すなわち, 診断や治療に対する今までの概 念は大幅に変わらさるを得なくなり, 脳神経外科の教 科書も次々と新しく書き換えられていった.ささらに今 後, 実用化されつつあるポジトロン CT や脳血管障 害の血管内処㯰手技の開発などを考えると, 脳神経外 科の発展は，正にとどまるところを知らぬ勢いであ る. 医学の長い歴史の中で, このような急速な進歩発 展を遂げた分野は，ほかに類をみないように思われ る.

一般に, 学問の進歩発展には, 常にそれを押し進め ようとする新しい原動力と，行き過ぎを抑えようとす る自制力によってうまく調整されていくものである。 ここでは，医学の中でもはなはだ専門的な分野と目さ れている脳神経外科領域の最近の進歩と動向について 触れるとともに，若干の反省を含めた考察を加え，合 わせて当教室における最近の 2,3 の論文を報告し御 批判を仰ぎたいと思う.
\end{abstract}

\section{1. 脳神経外科の歴史}

脳神経外科の歴史は非常に古い。穿頭術は古代から 行われていた形跡があり，その骨縁の生活反応から， 手術後もかなり長期間生存していたことが判明してい る.これらの穿頭術は, 当時てんかんや頭痛の患者の 頭蓋の中には悪霊が宿っていてこれらを引き起こすと いう考えから，悪霊を外に追い出すために行ったもの と想像されている. また，医聖 Hippocrates（460 377 B.C.) は, すでに頭部外傷の治療に穿頭術が必要

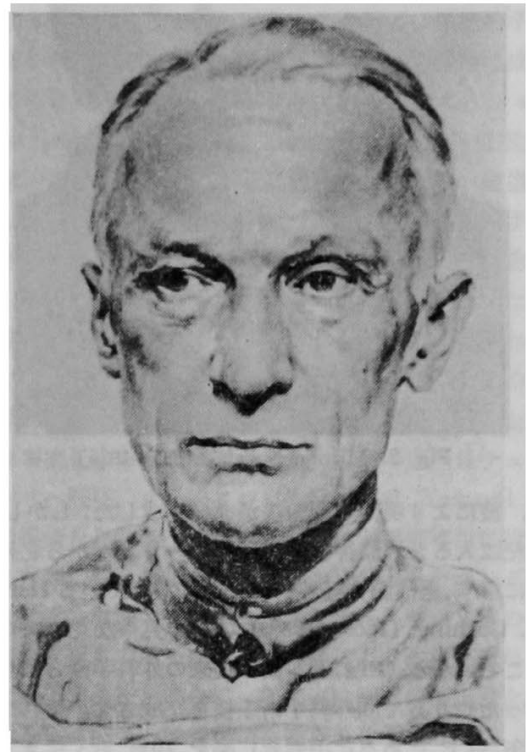

Fig. 1 Harvey Cushing (1869 1939)

であることを述べ,その手技を記載している。しかしそ の後中世 (1500 年代) からルネッサンス (1700 年代) を経て近代に至るまで, 譄神経外科も一般外科同様特 に目新しい進歩が慧められなかった.しかるに，19 世紀半ばから後半にかけて, 麻酔の発達と消毒法の完 成により，外科学が飛躍的な発展を遂げ，外科学の立 場から脳外科手術も行われるようになった. また, こ のころ神経学, 特に人脑の機能の局在に関する知見が 急速に進歩した. すなわち, Broca の言語中枢の発 見 (1860 年代) や Jackson の皮質性てんかんの解 明 (1870 年代), Ferrier の大脳皮質運動領野の証明 (1880 年代) など, 19 世紀後半における媨の解剖や 生理学, さらに神経学の急速な発達は, 外科学の進歩 と相まって, ここに新しい脳神経外科手術の開拓時代 を迎えることになる.この先䩙をつけたのがロンドン の脳外科医 Sir Victor Horsley (1857 1916) であ 


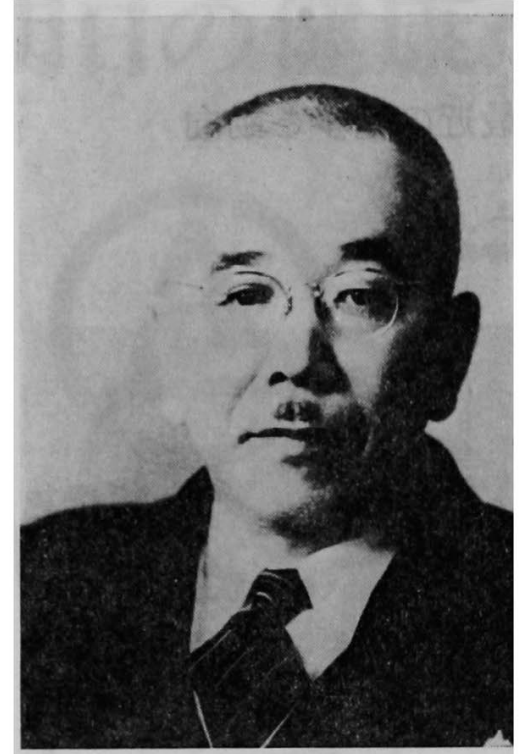

Fig. 2 Mizuho Nakata (1893 1975)

り，彼により現代の開頭法がほぽ完成した.しかし20 世紀に入ると，脳神経外科学はヨーロッパから北米大 陸に移り，近代脳神経外科の父と仰がれている Harvey W. Cushing（1869～1939）の下で見事な花を咲かせ ることになる(Fig.1). 彼は従来の外科手術とは全く 違ったやり方で脳外科手原手技を完成させ，それまで 50\% 以上であった手術死亡率を $10 \%$ 近くにまで引 き下げた.さらに脳神経外科の各分野において診療, 研究, 教育の幅広い活動を行い, 現代腹神経外科学の 基整を築き上げたのである. 彼の多数の弟子により欧 米では早くから專門化が進み，それらが今日の最も進 んだ米国の脑神経外科学を作りあげたとみてよいであ ろう.

一方，わが国における脑神経外科学は, 主にヨーロ ッパの流れをくみ，各地の外科医が散発的に行ってい たが，第 2 次世界大戦終結後の 1948 年ようやく第 1 回日本脂神経外科研究会が新潟の地で開催されるに至 った.これは欧米の脳神経外科学に比へ 20 年以上の 遅れをとったことを物語っている.しかし,わが国の脳 神経外科学の発展にとってきわめて幸運であったこと は, 当時先覚者としてこの道の指導的立場におられた 中田瑞䅼教授 (1893〜1975) が, ナでに 1920 年代後 半より米国の Cushing 流脑外科を日本の指標として いち早くとり入れられ、これを强く押し進められたこ
とである (Fig. 2). Boston で Cushing の手術を見 学された中田教授”が「これこそが膇外科医のあるべ き嫈である」と感嘆された話はあまりにも有名であ り, 当時のヨーロッパ流外科手術の華やかなりしころ を思うと, 素睛しい畫眼といわさるを得ない。これら の優れた指導者や個々の研究者の努力がそれぞれ実を 結んで, わが国の脑神経外科学も急速に 20 年来の遅 れを取り戻すに至る．そして 1965 年ようやく腷神経 外科㟝療科目が公認され，専門化が進むとともに, 現 在では欧米に比し決して称色のないレペルにまで達し ている. 特に治療面では Yasargil により開拓された microsurgery がいち早く各施設にとり入れられ， CTscan も米国に次ぐ世界第 2 の保有国として, 診断 と治療の両面における画期的な進歩がもたらされつつ 今日に至るのである.

\section{2. 脳腫瘍の治療における進步}

良性脑腫疼に対する診断や治療技術の進歩は, 深部 䏚腫瘍を除けばすでにいきつくところまで達した感が ある. 下垂体腺腫や頭蓋咽頭腫については, 経鼻的手 術の進歩やホルモン定量による治療上の進歩をあげる ことができるが，その中でもプロラクチン測定による プロラクチン産生下垂体腺腫（prolactinoma）が，最 近内科医や婦人科医の理解と協力の下で数多く発見さ れるようになった. 概してこれらの腫瘍は小さく、視 カ・視野の障害をきたすまでには至らず，無月経と乳 汁分泌を主訴に婦人科や内科を防九治療をうけている 場合が多い，頭蓋トルコ鞍に変化をきたすことも少な く発見が遅れがちであるが，最近の GE などによる 新型 CTscan 装置を使用し, 特殊撮影法を応用する ことにより発見が容易となった．治療法としては経鼻 的蝶形骨手術が推奖されているが, 新薬剂 bromocriptine (CB-154) の投与により, 腫疸は劇的に縮小・ 消失をみ, プロラクチン值も下降する例が多いので, 我々は2】こ種の腫瘍の治療には, 薬物療法を第一選 択としており, Baskin らすこの点を強調している. また邻膜腫については, 栄養血管の選択的塞栓法”や レーザーメス使用による術中出血量のコントロールが 得られるよらになり,さらに聴神経鞘腫については神 程耳科学および CTscan の進歩による早期発見と, microsurgery の技術向上に基うく顔面神経保存成績 の向上などを最近の治療の進歩としてあげることがで きよう.しかし悪性脳腫癔，特に悪性グリオーマや転 移性脱腫瘍に対しては，現在もなお治療成績はきわめ 
て不良であり，最近の脳神経外科学の進歩から完全に とり残された一角であるといえる.

本年 7 月ミュンヘンにおいて第 7 回国際脳神経外科 学会が開催され，その中で悪性脳腫瘍の治療法につい ての sessionがもたれ，各国の臨床医によりきわわて 活発な討議がくり広げられた.

覀性脳腫瘍の治療法には手術療法, 抗癌凧による化 学療法, 放射線療法が主要な治療法となり, これに免 疫療法が付加される.腫瘍は概して浸潤性で, 広く深 部にまで発育進展するため，手術による全摘除は不可 能で, 術後化学療法や放射線療法が行われるのが現状 である.ある種の腫場に放射線はきわめて効果的であ るが，正常脳一の影響があり照射線量に自ら制限が加 えられる. また免疫療法にしてもいまだ生体の免疫監 査機構を高める程度のものであり，大きな期待は望み 得ないのが現状である. 最近話題となっているインタ ーフェロンにしてもしょせん腫痬そのものの縮少効果 は望むべくむなく現在のところ最も期待されているの は, やはり手術療法に加え化学療法を効果的に使用す ることである.しかし化学療法を行う場合、睬には特 有な血朕関門があり，これは腫瘍によりある程度破壊 されているとはいっても，抗癌剤を全身的に投与する かぎり，腫瘍組織にとりこまれる抗癌剤の量はきわめ て微々たるむので, これが他满器の悪性腫㾔と最む異 なる治療上の厄介な問題を提起している.このため直 接脊憱有クモ膜下腔に投与する方法や内頝動脈内持続投 与法, さらにはマニトール併用静注法による透過性亢 進の期待など種々の投与法が考案されている. さら に, 胼腫瘍組織への䢪過性の高い薬版の開発なども行 われているが、いずれるいまだ決定的な方法は見出さ れていない.これに対し，我々は早くから局所注入療法 (local injection method) を考案して積極的な治療を 行ってきた ${ }^{5 \sim 7)}$. すなわち手術により严全摘した腫瘍 床内に Ommaya's tube を挿入し, その device を頭 皮下に固定してここより経皮的に直接腫瘍床内に抗癌 剤を注入する方法である (Fig. 3). 今回の学会で, こ の療法で治療を行った malignant glioma 17 症例の遠 隔成績や抗癌羭とりこみ洤度を中心に発表したところ 多大の反響を呼び, 特に米国の悪性媨腫瘍を Kaplan 方式で集計調查している Salcman 教授より賞賛され， 全症例の集計データを早急に送ってくれるように依頼 された（Table 1). 本療法にももちろん限界があり， 局所に投与された抗癌刜はわずか $2 \sim 3 \mathrm{~cm}$ の深部組 織までしか浸潤しないので，遠隔部腫癔には全身投与
法を併用する以外にない. しかし, 比較的限局した腫 瘍には本法はきわめて有効と思われ, 従来の方法では 到底考えられない長期生存例が次々に出現してきてい るのは嬉しいかぎりである. 幸い CTscan によって 細腫瘍の早期発見が可能になった現在, 本療法は悪性 㬝腫瘍の治療子後に一条の光をもたらすものと信して いる.

一方, 深部に局在する脳腫瘍は，たとえそれが比較 的小さくまた良性であっても, 生命および機能的予後 の面から従来は手術不可能とされ, たとえ手術に成功 しても意䤃障害の遷延する例が多い, しかるに, microsurgery の大家である Yasargil 教授は,第吕脳室, 視床・松果体部, 橋部などに局在するこれらの腫瘍に 対して,積極的なアプローチを行い, 術後の機能的予後 もきわめて良好な結果を発表された. これらの患者 が，術後の意識障害もなくバレーやダンスに興したり 自転車に乗ったりして，日常生活を常人と全く変わら ない姿で楽しんでいるスライドを見せられ，会場の一 同はたた整暎するのみであった，筆者はこのような劇 的な事実を自らの目で確かめるぺく, 早速一日チュー リッヒへ飛び, チューリッヒ大学で終日 Yasargil 教 授の手術を見学させて頂いた. 檤外科手術専用に設備 され整理の整った手術室で, かつ十分トレーニングさ れた助手や看護婦を相手に整然と行われている彼の手 術は実に見事であった．彼の考案により改良を重ねて きた顕微鏡手技を中心に，午前中は脳腫瘍摘出術を， 午後からは前交通動趺瘤の手術をみせてもらった. 脳

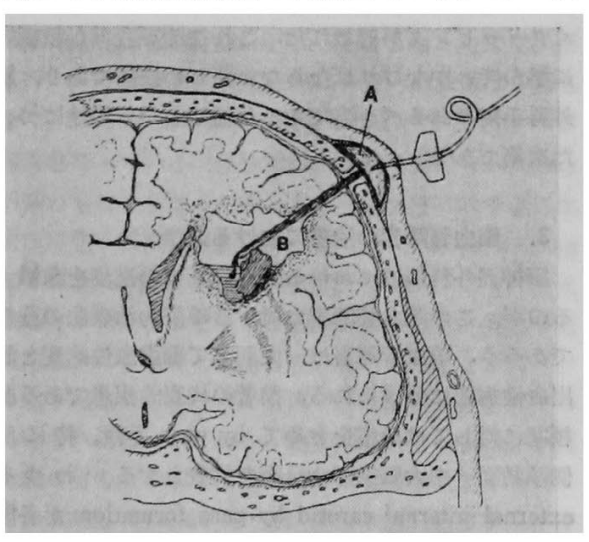

A : Ommaya's reservoir

B : Ommaya's tube

Fig. 3 Diagramatic representation of the technique of local injection method 
Table 1 Clinical data in the patients with malignant glioma treated with local injection of ADM

\begin{tabular}{|c|c|c|c|c|c|c|c|c|}
\hline case & age sex & ope. & $\begin{array}{l}\text { ADM dose } \\
(\mathbf{m g})\end{array}$ & $\begin{array}{l}{ }^{\circ 0} \mathrm{Co} \text {-irrd. } \\
\text { (rads) }\end{array}$ & Other Chemotherapy & immunotherapy & survival & $\begin{array}{l}\text { clinical } \\
\text { effect }\end{array}$ \\
\hline 1 & $32 \mathrm{M}$ & $\mathrm{ST}$ & 13.5 & 6,000 & - & + & $14 \mathrm{M}, \mathrm{Ex}$ & H \\
\hline 2 & $18 \mathrm{M}$ & ST & 6.0 & 6,000 & ACNU, VCR & + & $46 \mathrm{M}, \mathrm{Al}$ & 世 \\
\hline 3 & $58 \mathrm{~F}$ & $\mathrm{ST}$ & 5.0 & 4,500 & ADM-IA & + & $11 \mathrm{M}, \mathrm{Ex}$ & + \\
\hline 4 & $35 \mathrm{~F}$ & $\mathrm{ST}$ & 5.0 & 4,500 & $\mathrm{ACNU}, \mathrm{VCR}$ & + & $41 \mathrm{M}, \mathrm{Al}$ & H \\
\hline 5 & $56 \mathrm{~F}$ & $\mathrm{ST}$ & 5.0 & 5,000 & $\mathrm{ACNU}$ & + & 40M, Al. & 世 \\
\hline 6 & $47 \mathrm{~F}$ & $\mathrm{ST}$ & 10.0 & 5,000 & - & + & 10M, Ex. & + \\
\hline 7 & $49 \mathrm{M}$ & $\mathrm{ST}$ & 5.0 & 4,500 & ACNU, VCR & + & $25 \mathrm{M}, \mathrm{Al}$ & 世 \\
\hline 8 & $37 \mathrm{M}$ & $\mathrm{ST}$ & 5.0 & 4,000 & - & + & 24M, Al. & H \\
\hline 9 & $50 \mathrm{M}$ & S T & 10.0 & 6,000 & ACNU, VCR & + & $6 \mathrm{M}, \mathrm{Ex}$ & - \\
\hline 10 & $54 \mathrm{~F}$ & $\mathrm{ST}$ & 10.0 & 6,000 & ACNU, VCR & + & 4M, Ex. & - \\
\hline 11 & $51 \mathrm{M}$ & S T & 5.0 & 5,000 & M.F.C., ACNU, ADM & + & 9M, Ex. & + \\
\hline 12 & $35 \mathrm{M}$ & ST & 1.5 & 4,500 & $\mathrm{ACNU}, \mathrm{VCR}$ & + & $12 \mathrm{M}, \mathrm{Al}$ & $H$ \\
\hline 13 & $29 \mathrm{M}$ & S T & 3.0 & 5,000 & ACNU, VCR & + & 12M, Al. & $H$ \\
\hline 14 & $57 \mathrm{~F}$ & S T & 5.0 & 4,500 & ACNU, VCR & + & 9M, Al. & $H$ \\
\hline 15 & $62 \mathrm{M}$ & S T & 5.0 & 5,000 & ACNU, VCR & + & 12M, Al. & H \\
\hline 16 & $35 \mathrm{M}$ & S T & 5.0 & 4,500 & ACNU, VCR & + & 6M, Al. & $H$ \\
\hline 17 & $31 \mathrm{M}$ & ST & 5.0 & 6,000 & ACNU, VCR & + & 11M, Ex. & + \\
\hline
\end{tabular}

ST : subtotal removal, Ex : expire, Al : alive, ADM : adriamycin

腫演の手術では，脳瑇への切開をわずか $2 \mathrm{~cm}$ 以内に とどめ，決して血管を損稘せず，脳べらによる牽引も 最小限度に抑えて腫瘍自体に到達し, 腫瘍のみの摘出 を行う彼の手技は神技に近く、これらをつぶさにみて ようやく発表された事実を信用することができた.す なわち深部腷腫湯の摘除を行っても, 腫瘍部分のみが 除去されるだけで, 他の健常組織はほとんど倁ついて いないのである．脳動脈瘤の手術においても，ついに 脳組織やそれにまつわる血管は 1 本も甥つけることな くクリッピングが行われた.これこそが我々が積極的 に学んでいかなければならない新しい技術であり，脳 外科手術のあるべき姿であると信しながら㷌途につい た次第である.

\section{3. 脑血管障客の治療における進步}

脳神経外科領域における最近の最大の進歩を象徵す るのが、この脳血管障害に対する手術的治㙩法の達成 であろう、脳血管障害は, 大別して媨虚血性病変と脳 出血性病変に分けられる. 前者の代表的疾患である脳 梗塞に対しては適応をきめて by pass 手術, 特に浅 側頭動脈一中大脳動脈吻合術を代表とするいわゆる external-internal carotid by pass formation が各国 で盛んに行われており，現在その成果が，カナダのウ エスタンオンタリオ大学を事務局として国際共同研究 の形で検討されつつある.本疾患はわが国でもきわめ て頻度の高いものであるから，一層この共同研究の成
果が期待されている. また後者，すなわち脳出血性病 変の代表として，クモ膜下出血と高血圧性脳出血があ げられるが、これらの疾㭧に対する外科的手術適応に ついて，わが国と欧米諸国の間でかなりの開きがあ る.このギャップはいずれ我々が埋めていかなければ ならないのでここで触れておくこととする。

まずクモ膜下出血の元凶と目されている脳動脈細に 対しては，欧米では一般に早期手術は行われておら す，患者の状態の安定を待ってから手術がなされる. これに対し，日本では脳動脈㴏破裂後 3 日以内の超早 期手術が，術後の脳血管弯縮も少なく成綪がよいと主 張され，一般に早期手術が強く推奖されている.しか しこれに対し、ドイッ脳神経外科学会の権威者である Pia 教授は, 発症後 3 日以内に行う手術が稱血管孪縮 を防ぐという日本人の主張には全く根拠がなく，また 早期手術は手術死亡率が高く，かつ機能的予後の悪い ことから決して推奖さるべきではないことを，自駼例 を中心に厳しく批判された.これに対し，早期手術の 推奖者である日本の某教授が，自分の行った早期手術 の成績が悪くはないことをほのめかした際，Pia 教授 は満身に怒りをこめて、「あなたのデータは選択に選 択を重ねた症例のみを手術したものであり，全く信用 できないものだ」ときわめて笠しい口調で批判された のがはなはだ印象的であった.このように外国の研究 者は，作為的なデータや信ぴょう性の薄いデータをそ の発表者とともに極端に嫌う．これは今回の国際雮神 


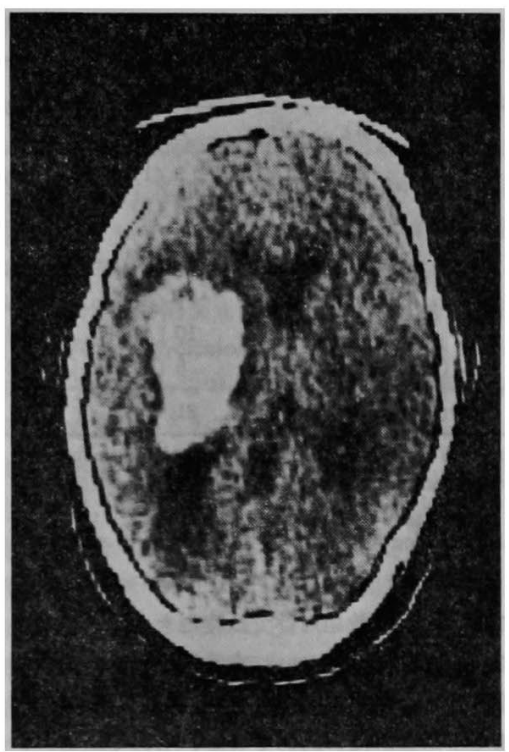

Fig. 4 CT scan of putaminal haemorrhage extended to the anterior and posterior limbs

経外科学会でも随所に見られた. すなわち数值上の 好成績がどのように並べられていても，それに信び よう性がなれば全く無視され，倎問もコメントも 出ないのである. chairmanを務められた Bagchi 教授 も「信ぴょう性のある paper かどうかは口演内容を きけばすぐ分かる．我々はそれらをすへでチックし ながら口演をきいているが, good paper は非常に少 ない」と算しい批判を下しておられた.

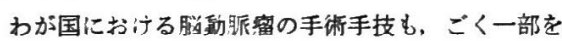
除きほとんどの施設では microsurgery による媨の愛 護的手術法がとられている.ただ残念なことは，わが 国の各施設における运動脈疾の手術成績が，死亡率を 下げることにのみ使われて招り, morbidity を含めた 具体的な内容に螌れているものがきわめて少ないこと である. すでに Pia 教授により指摘されているごと く ${ }^{8)}$, 無選択に行われた早期脳動派䍠の手術死亡率は 極端に高く、また morbidity も高いのは常識である。 ここに当然選択がなされなければならないはずで，そ れには具体的で正確な各施設からのデータが必要とな る. 特に破裂兽動脈蜜の早期の病態の解明と, 年令や 動脈瘤の部位による腷循環動態の解明が早期手術適応 を決定する大きな踺となるであろう．Alksne らきは

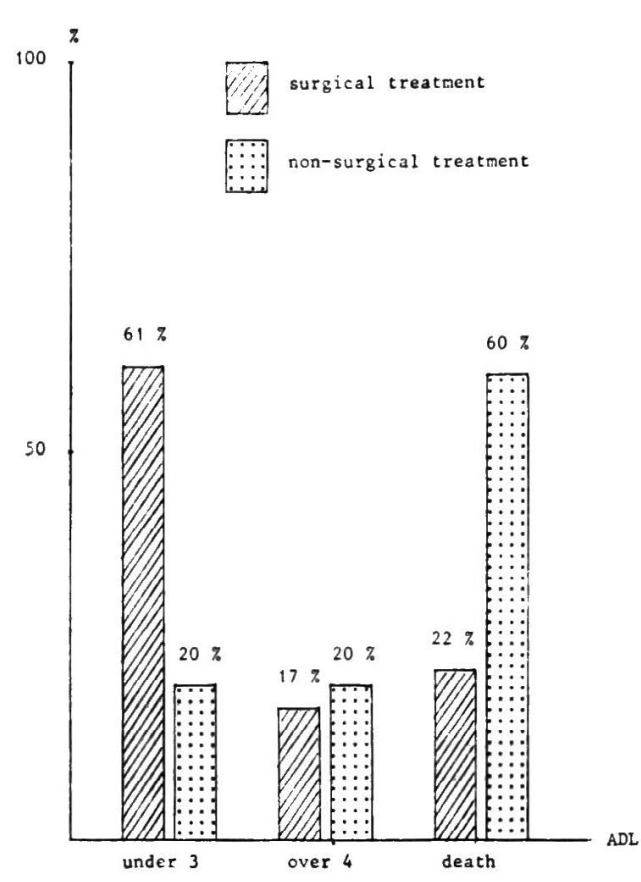

Fig. 5 Comparative study of CT classification IVa group CT classification $\mathrm{Va}$ : extended to the ant. and post. limbs.

いずれも重症な前交通動脈瘤 22 例に, 定位的脂手術 手技を用いて，カテーテル法により iron-acrylic mixture を直接動脈瘤内に注入し凝固させる方法で手術 を行い, その結果手術死亡率は 0 で再出血例は 1 例も なく, 16 例が元の職場に復帰したという注目すべき 報告を行っている. 急性期脳動脈瘤手術の morbidity が高いものならば, このような手術手技に対する根本 的な発想の転換も必要であろう.いわゆる challenging operation は推奖さるぺき手術法ではない, 将来は 特殊なカテーテルを用いた脳動脈瘤の血管内処置手術 が達成されるものと期待している.このことは同じ モ膜下出血のもう一つの元凶である脳動静脈奇形につ いてもいえる.すなわち, 脳動静脈奇形む脳深部や脳 幹部のものは手術不可能か行っても成績はよくない. これに対し Mullan ら ${ }^{103}$ やはり選択的カテーテル 法による栓塞術が有効であることを指摘しており，ま た Cromwell ら ${ }^{11}$ はポリマー化学物質の注入による 栓塞法とこれにつゔく全摘術で良好な結果が得られる ことを强調している.このように䈪血管外科手術も， 
Table $2 \mathrm{CT}$ findings and outcome of primary brain stem injuries

\begin{tabular}{|c|c|c|c|c|c|c|c|c|c|c|}
\hline \multirow{2}{*}{ CT Findings* } & \multicolumn{3}{|c|}{ Glasgow Coma Scale } & \multirow{2}{*}{$\begin{array}{l}\text { No. of } \\
\text { Patients }\end{array}$} & \multicolumn{5}{|c|}{ Glasgow Outcome Scale** } & \multirow{2}{*}{ [Mortality] } \\
\hline & 3 & 4 & 5 & & GR & MD & SD & Veg & Dead & \\
\hline $\mathrm{BSH}$ & $1(0)$ & $2(1)$ & $2(1)$ & $5(2)$ & $1(1)$ & 0 & 0 & $1(0)$ & $3(1)$ & [60\%] \\
\hline COMB & $5(1)$ & $4(1)$ & $3(3)$ & $12(5)$ & $2(2)$ & $2(0)$ & 0 & 0 & $8(3)$ & [66.796] \\
\hline IVH & $1(0)$ & 0 & $2(2)$ & $3(2)$ & 0 & 0 & 0 & 0 & $3(2)$ & {$[100 \%]$} \\
\hline $\mathrm{PCB}$ & 0 & $1(0)$ & 0 & $1(0)$ & 0 & 0 & 0 & 0 & $1(0)$ & [100\%] \\
\hline SAHB & $1(0)$ & 0 & 0 & $1(0)$ & 0 & 0 & 0 & 0 & $1(0)$ & [10096] \\
\hline MIX & $3(1)$ & $5(1)$ & $2(2)$ & $10(4)$ & 0 & 0 & 0 & 0 & $10(4)$ & {$[100 \%]$} \\
\hline NP & $2(1)$ & $4(2)$ & $2(1)$ & $8(4)$ & $1(1)$ & $1(1)$ & 0 & $1(0)$ & $5(2)$ & {$[62.5 \mathrm{c}]$} \\
\hline Total & $13(3)$ & $16(5)$ & $11(9)$ & $40(17)$ & $4(4)$ & $3(1)$ & 0 & $2(0)$ & $31(12)$ & \\
\hline
\end{tabular}

* $\mathrm{BSH}=$ brain stem hemorrhage; $\mathrm{COMB}=$ compressed basal cisterns; IVH=intraventricular hemorrhage in the IV th ventricle; $\mathrm{PCb}=$ pneumocephalus in the basal cisterns; $\mathrm{SAHB}=$ subarachnoid hemorrhage in the basal cisterns; MIX=mixed type $: \mathrm{NP}=$ nothing particular

** $\mathrm{GR}=\mathrm{good}$ recovery; $\mathrm{MD}=$ moderate disability; $\mathrm{SD}=$ severe disability; $\mathrm{Veg}=$ vegitativ ( ) =child or children

従来の方法から徐々に新しい流れに変わりつつあるこ とを痛切に感ずる.

高血圧性脳出血の外科的治療は, Cushing (1903) 以 来の悲願であったが,その後 McKissock ら (1961) ${ }^{12)}$ の詳細な報告がなされ，結局外科的治療と内科的治療 とに差異のないことが分かってから，欧米では大媨皮 質下および小腷以外の大脳基底核部出血に対方る手術 的治療はあまり行われていない，これに対しわが国に おいては最近の約 10 年間に積極的な外科治療が行わ れた. 特にCTscan の出現により，血腫の部位や進 展方向, さらに血腫量などが容易に診断できるように なり，特に被殻出血に対して，CTscanによる血腫部 位の進展による分類と臨床所見による神経症状の基準 が設けられ、これに則って外科的手術の適応が検討さ れた. 我々も当院救命敕急センター, 内科および関連 病院の協力の下で, 被殻出血 71 例 (外科治療群 39 例：内科治療群 32 例）を集計し比較検郡した結果, 次の結論に達した ${ }^{18)}$. すなわち，手術適応として機能 的にも（ADL 3 以下）また救命率加らも内科療法よ り優机ている群は CTscan 上, 内包前脚後脚進展型で (CTclassification $\mathrm{Ia})$, 出血量も中等度 $(20 \mathrm{~m} l$ 前後), かつ意識レベルが昏睡に至らない程度のものと限定さ れた (Fig 4, 5). そして, それ以下の柽症例やえれ 以上の重症例は, morbidity の点でも内科療法と変わ らないという成績が得られ，これらの適応はその後の 多くの人達の替同を得ている. また年令や左右大脳半 球による機能的予後にも差がなく，一部の人達によっ て推奖されている超早期手術は，むしろよくないこと が分かった. 老年者が大多数を占めるこの種の手術に
関しては, 単なる救命だけでは寝たきり老人をつくる のみで全く意味をなさない. 当然術後の機能的予後か 最も重視されなければならない.この点を十分ふまえ た適確な手術適応はきわめてせまいものであることを 再確認した次第である。また，外科的治療の対象とは ならない視床出血も，内科療法だけで予後の良好とな る例が多く，従来考えられていたよりも遙かに後遗症 の少ないことか゚ CTscan を通しての follow up study で明らかにされた.しかしこれらの中で，媨室穿破を きたした症例は，また別の角度から予後の判定がなさ れなければならないことは当然といえようい。

\section{4. 頭部外伤の治療における進步}

CTscan の出現により，頭部外甥の診断および治療 法もまた大きく進展した.わが国でよく用いられてい た荒木の分類は CT 所見との対比で，かなりの差異 のあることが指摘されており，CTscan 上の分類が武 みられている. また今まで視覚的診断の不可能であっ た媨浮腫はその程度まで CTscan で適確にとらえられ るようになり，脳挫甥やそれに起因する遅発性媨内血 腫, 後頭蓋窝血腫, 脑幹部損稘, 脳へルニアなどが明 確になり，最近ではこれらの発生機序の解明に力が注 がれている(5). もちろんこのような視賞的診断技術 の進歩が治療面に果たす役割は大きく，頭蓋内圧克 進や脳浮腫に対する治療法の向上と相まって, 重症頭 部外賃の治療成績も向上してきている.こうした中 で, 我々は特に䏚幹部損傷に注目( ${ }^{18)}$, 当院救命救急 センターとの協力下で治療を行った重症頭部外傷例の 中から，外傷性 1 次性媨幹部損傷例を集計し，CT scan による classification と予後判定との関係を究明した 
(Table 2). 頭部外鹪の予後を決定する最も重要な因 子が脳幹部損稘の有無やその程度であることは, すで に古くから考えられていたが，その病態が形態学上か らもまた脳幹機能の面からも究明されてきたのはごく 最近のことで,これらの研究に今後の治療への期待が 寄せられている. 今まで行われてきた持続脳圧测定に よる頭蓋内压変動のパターンや脳幹聴賞反応などのほ かに, 内分泌学的検查を中心とした液体生化学的検查 が予後判定の indicator として注目されるようになる

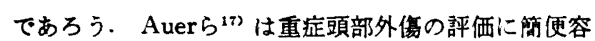
易な検查所見のうちよく予後と相関するものを求め, 血清法透圧, 尿秦, 血糖, ビリルビン值, 痛み回避反 応, 体温, 呼吸および対光反射の 8 種が有用な予後判 定所見となることを示した.これらをコンピュータ処 理により解析すると, 受傷後 4 日間で予後判定が可能 なものは 80\% であったという. さらに統計的処理を 行った報告の中で, 副腎皮犋ホルモン大量投与は, 重 症頭部外傷になんらの治療成績の向上をもたらさない ことが指摘されている ${ }^{18)}$. 筆者は当初から副腎皮質ホ ルモンの䏚浮腫䂆防に対する大量投与㙩法に批判的で あり，機会あることとにその乱用をいましめてきたが19， 20), これらの新しい統計的処理を信頼し，速やかに治 療の方針を変えていかなければならないと思う．また 最近話題となっているバルビツレート大量投与も，頭 蓋内压低下には勃果があっても，一方において脳灌流 圧を低下させるという久点があり ${ }^{21)}$ ，乱用はつつしま なければならない：その他頭部外傷に対する注目すべ き話題として，慢性硬膜下血腫成因に関する CT およ び臨床的知見 ${ }^{22}$ や意祴障害を中心にした小児頭部外傷 の特殊性 ${ }^{23.26)}$, 外旐による特殊な合併症 ${ }^{25}$-28) 等々枚 挙にいとまがないが、いずれもCTscan を駆使した新 事実の発見が中心となり，それらが適確な治療面への 直結となって現れているここでは主として当教室で 最近報告した論文を参考に供した.

\section{おわりに}

最近めざましい発展を遂げつつある脳神経外科領城 の 2. 3 のトピックスについて, 今後の動向を子まえ た概説を試みた. 大切なことは, 脂神経外科学の歴史 は決して単独にはあり得ず, 常に他科との密接な関連 の下で，「患者の治療を中心に」進歩発展してきたと いうことにある. 多くの人々の理解の上に立って，今 後益々正しい発展を遂けることを期待してやまない.

\section{文 献}

1）中田瑞䄼：外科今昔. p. 22 23, 文光堂, 東京, 1958 .

2）小林土郎, 志村拨郎, 中沢省三: CB-154 投与により

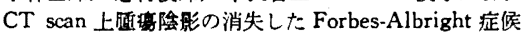
群の 1 例. Neurological Surgery (Tokyo), 8，463〜 467, 1980.

3) Baskin, D.S., and Wilson, C.B. : Bromocriptine treatment of pituitary adenomas. Neurosurgery, 8 , 741 744, 1981.

4) Hieshima, G.B., Everhardt, F.R., Mehringer, C. M., Tsai, F.. Hasso, A.H., Grinnell, V.S., Pribram, H.F., and Mok, M. : Preoperative embolization of meningiomas. Surg. Neurol., 14, 119 127, 1980.

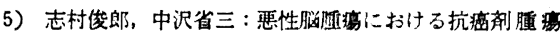
内局所注入法の矮床病理学的研究. Neurological Surgery (Tokyo), 8, 35 42, 1980.

6）志村优郎，中沢省三，伊藤保博，小林士郎，估藤茂，

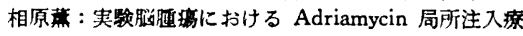
法の病理学的研究. Neurological Surgery (Tokyo), 9, 799 806, 1981.

7）中沢省三，大脇深，志村俊郎，伊藤保博, 矢岶浩三 : 悪

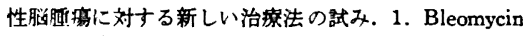
局所注入療法について. Neurological Surgery (Tokyo), 9, 1487 1493, 1981.

8) Pia, H.W. : Grading of cerebral aneurysms and the timing of operation. Neurosurgery., 4, 143 150, 1981.

9) Alksne, J.F., and Smith, R.W. : Stereotaxic ooclusion of 22 consecutive anterior communicating artery aneurysms. J. Neurosurg., 52, 790 793, 1980.

10) Mullan, S., Kawanaga, H., and Patronas, N.J. : Microvascular embolization of cerebral arteriovenous malformations; A technical variation.J. Neurosurg. 51, 621 627, 1979.

11) Cromwell, L.D., and Harris, A.B. : Treatment of cerebral arteriovenous malformations; A combined neurosurgical and neuroradiological approach. J. Neurosurg., 52, 705 708, 1980.

12) McKissock, W., Richardson, A., and Taylor, J. : Primary intracerebral haemorrhages a controlled trial of surgical and conservative treatment in 180 unselected cases. Lancet, 2, 221 226, 1961.

13）上田建志, 桶口晧史, 大脇楔, 矢鶝浩三, 中沢省三：

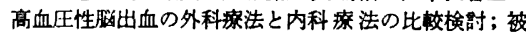

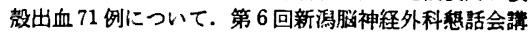
演集, p. 31 34, 新渴, 1980.

14）池田幸穗，教口皓史，上田建志，中沢省三：脑血管障 害に上る脳室内出血急性期死亡例の梌璟. 佼成病医 誌, B, 12 19, 1981.

15）中沢省三:腃浮腫の面加ら. Brain Nerve (Tokyo), 32, $25 \sim 35,1980$.

16）小林士郎, 中沢省三，有贺徹，矢埜正実，大挥敏文,

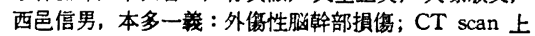
high density を呈した症例より. Neurological Surgery (Tokyo), 8, 1165 1174, 1980.

17) Auer, L.M., Gell, G., Richling, B., Oberbauer, R., Clarici, G., and Heppner, F. : Predicting lethal 
$-8-(718)$

outcome after severe head injury-a computer assisted analysis of neurological symptoms and laboratory values. Acta Neurochir., 52, 225 238, 1980.

18) Hernesniemi, J., and Troupp, H. : A retrospective study on the effects of low and high doses of betamethasone on severe closed head injury. Acta Neurochir., 51, 149 155, 1980.

19）中沢省三：脳浮埂の治療対策. 日医師会誌，68，805〜 817, 1972.

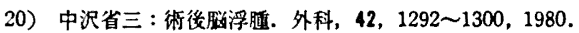

21) Clubb, R.J., Maxwell, R.E., and Chou, S.N. : Experimental brain injury in the dog; The pharmacological effects of pentobarbital and sodium nitroprusside. J. Neurosurg., 52, 189 196, 1980.

22）蕾原正昭, 池田幸理, 野手洋治, 松本正博, 矢岶浩三, 中沢省三：慢性硬膜下血䏣のCT 所見を中心とした分 析. 神释外伤, 3, 173 178, 1980.

23) Takahashi, H., and Nakazawa, S. : Specific type of head injury in children; Report of 5 cases. ChiId's Brain, 7, 124 131, 1980.
24）高檽弘，中沢省三：成人と比较した小永急性外伤性 頭 蓝内血腫の臨床的柃璟；特に意醅障害バターンを中心 として. Neurological Surgery (Tokyo), 9, 51 57, 1981.

25）池田幸穂, 中沢省三, 山川和臣, 小林士郎, 辻之英,

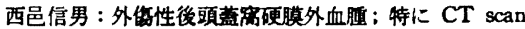
の有用性について. Neurological Surgery (Tokyo), 9, 401 406, 1981. 1981 .

26）陳茂楠，抒口晧史，伊藤保博，矢嶋浩三，中沢省三 : 眼窝壁穿破による檤損伤の 4 例. 外科, 43, 396 400, 1981.

27）小林士郎, 有賀徹, 大塚敏文, 西邑信男, 本多一義, 中沢

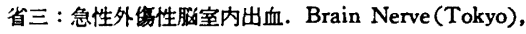
33, $715 \sim 724,1981$.

28) Ikeda, Y., Otsuka, T., Nishimura, N., and Nakazawa, S. : Posttraumatic stenosis of the middle cerebral artery with a contralateral intracerebral hematoma. Surg. Neurol., 16, 88 91, 1981.

（受付 : 1981 年 10 月 29 日) 